\title{
Does Storage under Gene Bank Conditions Affect Seed Germination and Seedling Growth? The Case of Senecio morisii (Asteraceae), a Vascular Plant Exclusive to Sardinian Water Meadows
}

\author{
Alba Cuena-Lombraña ${ }^{1,2, *}$, Martina Sanna ${ }^{2}$, Marco Porceddu ${ }^{1,2}\left(\mathbb{D}\right.$ and Gianluigi Bacchetta ${ }^{1,2} \mathbb{C}$ \\ 1 Department of Life and Environmental Sciences, Centre for the Conservation of Biodiversity (CCB), \\ University of Cagliari, Viale Sant'Ignazio da Laconi, 11-13, 09123 Cagliari, Italy; \\ porceddu.marco@unica.it (M.P.); bacchet@unica.it (G.B.) \\ 2 Sardinian Germplasm Bank (BG-SAR), Hortus Botanicus Karalitanus (HBK), University of Cagliari, \\ Viale Sant'Ignazio da Laconi, 9-11, 09123 Cagliari, Italy; m.sanna17@studenti.uniss.it \\ * Correspondence: alba.cuena@unica.it
}

Received: 16 April 2020; Accepted: 30 April 2020; Published: 2 May 2020

\begin{abstract}
Understanding seed viability under long-term storage conditions provides basic and useful information to investigate the effectiveness of seed banking. Besides the germination success, seedling establishment is also an important requirement, and a decisive step to ensure plant propagation. We used comparative data of germination, seedling growth, and survival percentage between fresh and 10-years-stored seeds of Senecio morisii, a narrow endemic and vulnerable species of Sardinia (Italy), in order to evaluate if differences exist in these traits between fresh and 10-years-stored seeds. Stored seeds showed higher germination percentages than fresh ones, whereas seedling growth and survival did not present significant differences between them, except for seedling growth in plants produced from seeds germinated at $25^{\circ} \mathrm{C}$. This study allowed us to assess if seeds of $S$. morisii were able to germinate under controlled conditions, and if they maintained their viability and germination capacity for at least 10 years of long-term storage in the seed bank. In addition, the high seedling survival detected in both fresh and stored seeds suggests that stored seeds of $S$. morisii can be used to support reinforcement or reintroduction actions when fresh materials are not available.
\end{abstract}

Keywords: ex situ conservation; long-term storage; seed banking; seed viability; survival; restoration programs

\section{Introduction}

Seed banking, as an integral part of the ex situ conservation, has a pivotal role in safeguarding plant species for long times in order to avoid loss of genotypes from populations. Ex situ conservation is complementary to in situ methods, serves as a source of material for in situ conservation actions [1-3] and, for some species, it might be the only option for their preservation [4,5]. About $45 \%$ of Europe's vascular plants are considered threatened, according to IUCN criteria [6]. Furthermore, Target 8 of the Global Strategy for Plant Conservation (GSPC) calls for "at least 75\% of threatened plant species in ex situ collections, preferably in the country of origin, and at least $20 \%$ available for recovery and restoration programmes" $[7,8]$. Therefore, extra attention is necessary to ensure the ex situ conservation of endangered plants in seed banks and to develop effective germination and multiplication protocols for these species.

Seed banking is a particularly important conservation strategy for species with orthodox seeds (desiccation-tolerant, sensu [9]). These seeds can be gradually dried at $15{ }^{\circ} \mathrm{C}$ and $15 \%$ of relative 
humidity $(\mathrm{RH})$, in order to reach ca. $3 \%-5 \%$ of internal seed moisture content, and then stored safely at temperature near to -18 and $-25^{\circ} \mathrm{C}$ [10]. Seed storage conditions maintain germplasm viability for several years, but even under suitable conditions, viability might decline over time [11]. Seeds of some species can remain viable for hundreds of years, while seeds from other species can only survive for few years [12,13]. For this reason, it is necessary to assess periodically the viability of seeds stored in seed banks. International guidelines and standards indicate that the viability of stored collections should be tested every five or 10 years [12,14-17]. Loss of seed viability and seed dormancy due to seed ageing have been found in many species $[13,18-20]$, and are caused by metabolic changes and DNA deterioration [21].

Seed germination studies have also been suggested to be performed in order to evaluate the effective viability of stored seeds [22]. For instance, seedling establishment and survival are vital to guarantee the persistence and multiplication of plant populations, and the successive effectiveness of restoration strategies [23]. Consequently, knowledge of the germination process, seedling establishment, and survival of threatened species are important for conservation practitioners, enabling them to produce plants and to increase the chance for establishment of self-sustaining populations [24,25].

In this paper, we studied the germination capacity of a threatened and narrow endemic species of Sardinia (Italy), Senecio morisii J.Calvo \& Bacch. Existing within the genus Senecio L. (Asteraceae), one of the largest genera of flowering plants, almost cosmopolitan and occurring in all the five regions with a Mediterranean climate [26], this species forms part of the Senecio doria L. group, a species complex of perennial herbs from Europe, western and central Asia, and northwestern Africa [27]. S. morisii was recently described from central-eastern Sardinia; it is a hygrophilous species which grows on water meadows or watersides with calcareous soils (limestones, travertines, and conglomerates) [27]. In particular, it lives along the edges of streams in woods of Ostrya carpinifolia Scop. accompanied by Taxus baccata L. and Ilex aquifolium L., between elevations of 700-1200 m a.s.l. [26]. S. morisii flowers from late May to July; the ligulate florets produce achenes, subcylindrical and glabrous, at the end of July, and no information about its germination traits is currently available. Only six populations are currently known $[27,28]$ and it was assessed as Vulnerable (VU) in the IUCN Italian Red List [29].

Comparative data of seed germination, seedling growth, and survival percentage between fresh and 10-years-stored seeds of $S$. morisii were used to address the following questions: (1) have fresh and stored seeds the ability to germinate?; (2) if yes, are there differences in germination between fresh and stored seeds?; and (3) are there differences in seedling growth and survival between fresh and stored seeds?

\section{Results}

\subsection{Seed Germination}

Generalized linear models (GLMs) show that seed germination under different conditions (stored or fresh) and incubation temperatures were significantly different $(P<0.001$, Table S1), also according to the two-way interaction $(P<0.01$, Table S1). Seeds stored (SS) for 10 years showed high germination percentage at all tested temperatures (Figure 1a). In general, all the SS achieved more than $50 \%$ of final germination percentages (FGPs), except at $5{ }^{\circ} \mathrm{C}(30.00 \pm 5.00 \%)$ and at $30^{\circ} \mathrm{C}(49.85 \pm 12.63 \%)$ (Figure 1a). FGPs ranging from $60 \%$ to $70 \%$ at the temperature range from $10{ }^{\circ} \mathrm{C}$ to $25^{\circ} \mathrm{C}$ including alternate temperature, were as follows: the highest FGPs were detected at $10^{\circ} \mathrm{C}(69.79 \pm 10.33 \%)$, followed by $15{ }^{\circ} \mathrm{C}(66.39 \pm 8.02 \%), 25^{\circ} \mathrm{C}(65.44 \pm 8.48 \%), 25 / 10{ }^{\circ} \mathrm{C}(62.36 \pm 23.90 \%)$, and $20^{\circ} \mathrm{C}(62.26 \pm 11.42 \%)$. On the other hand, fresh seeds (FS) did not reach $50 \%$ of germination at any incubation temperature (Figure 1a). The highest FGP was achieved at $30^{\circ} \mathrm{C}$ with $42.50 \pm 9.47 \%$, followed by germination at $15{ }^{\circ} \mathrm{C}(31.23 \pm 3.90 \%), 20^{\circ} \mathrm{C}(23.90 \pm 5.34 \%), 25 / 10{ }^{\circ} \mathrm{C}(23.59 \pm 14.71 \%)$, and $25^{\circ} \mathrm{C}(20.22 \pm 12.30 \%)$. The FS showed a FGP lower than $20 \%$ at 5 and $10^{\circ} \mathrm{C}$. 
Regarding the viability (Figure $1 \mathrm{~b})$, no significant differences $(P>0.05$, Table S2) were detected by GLM between seed conditions (SS and FS) and the two-way interactions (seeds and temperature conditions). While incubation temperatures were slightly significantly different $(P=0.05$, Table $S 2)$, the subsequent post hoc highlighted significant differences at $5{ }^{\circ} \mathrm{C}(P<0.05$, Figure $1 \mathrm{~b})$. Analyzing the dormancy index (DI), values were particularly high in FS (Figure 1c). DI in FS at temperature range from $10^{\circ} \mathrm{C}$ to $30^{\circ} \mathrm{C}$ was higher than the threshold value of dormancy $>0.4$, while only the DI value for $5^{\circ} \mathrm{C}$ was less than 0.2. For SS, DI was less than 0.2 in all tested temperature conditions (Figure 1c).
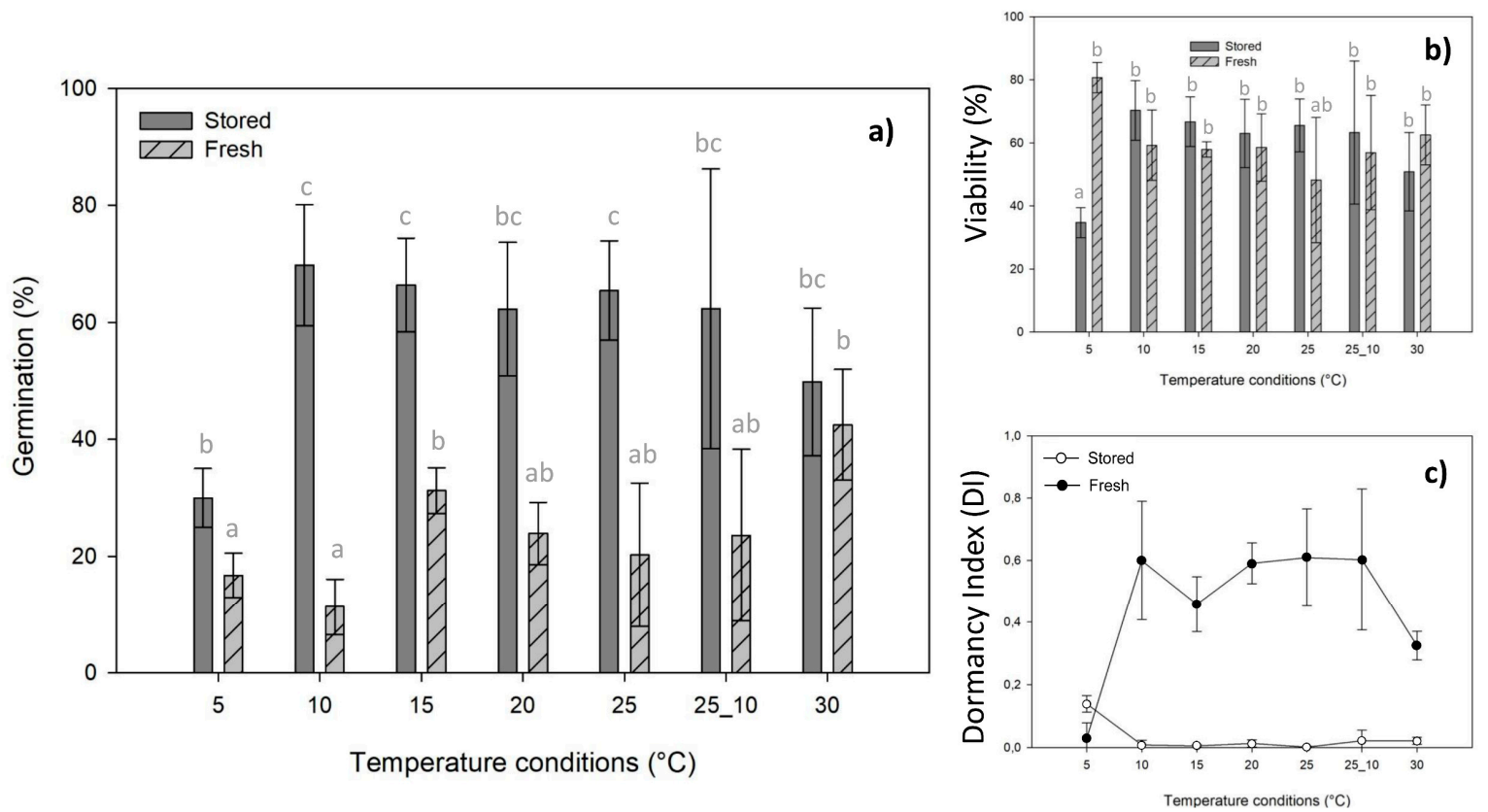

Figure 1. (a) Final germination percentages (FGPs) achieved at the end of the germination tests for each seed conditions (stored and fresh). (b) Percentage of seed viability at the end of the germination tests. Seed viability was calculated as sum of germinated seeds and filled seeds. Post hoc pairwise $t$-test comparisons were carried out for each germination temperature, and bars with different letters $(\mathrm{a}, \mathrm{b}, \mathrm{c})$ indicate significant $(P<0.05)$ differences. (c) Dormancy index (DI) by temperatures of stored and fresh seeds at the end of germination tests.

\subsection{Seedling Growth and Survival Percentage}

The leaf length of seedlings belonging to SS and FS (Figure 2), measured during 120 days under greenhouse conditions at $18^{\circ} \mathrm{C}$, did not show very significant differences $(P>0.01$, Table S3), except for the seedlings obtained from germinated seeds at $25^{\circ} \mathrm{C}(P=0.003$, Table S3). The highest leaf lengths for SS were found in seedlings derived from germinated seeds at $25^{\circ} \mathrm{C}(6.58 \pm 2.96 \mathrm{~cm})$, followed by $15^{\circ} \mathrm{C}(5.95 \pm 1.62 \mathrm{~cm})$, and $20^{\circ} \mathrm{C}(5.38 \pm 2.37 \mathrm{~cm})$. Regarding the FS, the highest leaf lengths were detected in seedlings from germinated seeds at $15^{\circ} \mathrm{C}(4.11 \pm 1.90 \mathrm{~cm})$ and $25 / 10^{\circ} \mathrm{C}(2.85 \pm 1.37 \mathrm{~cm})$. 

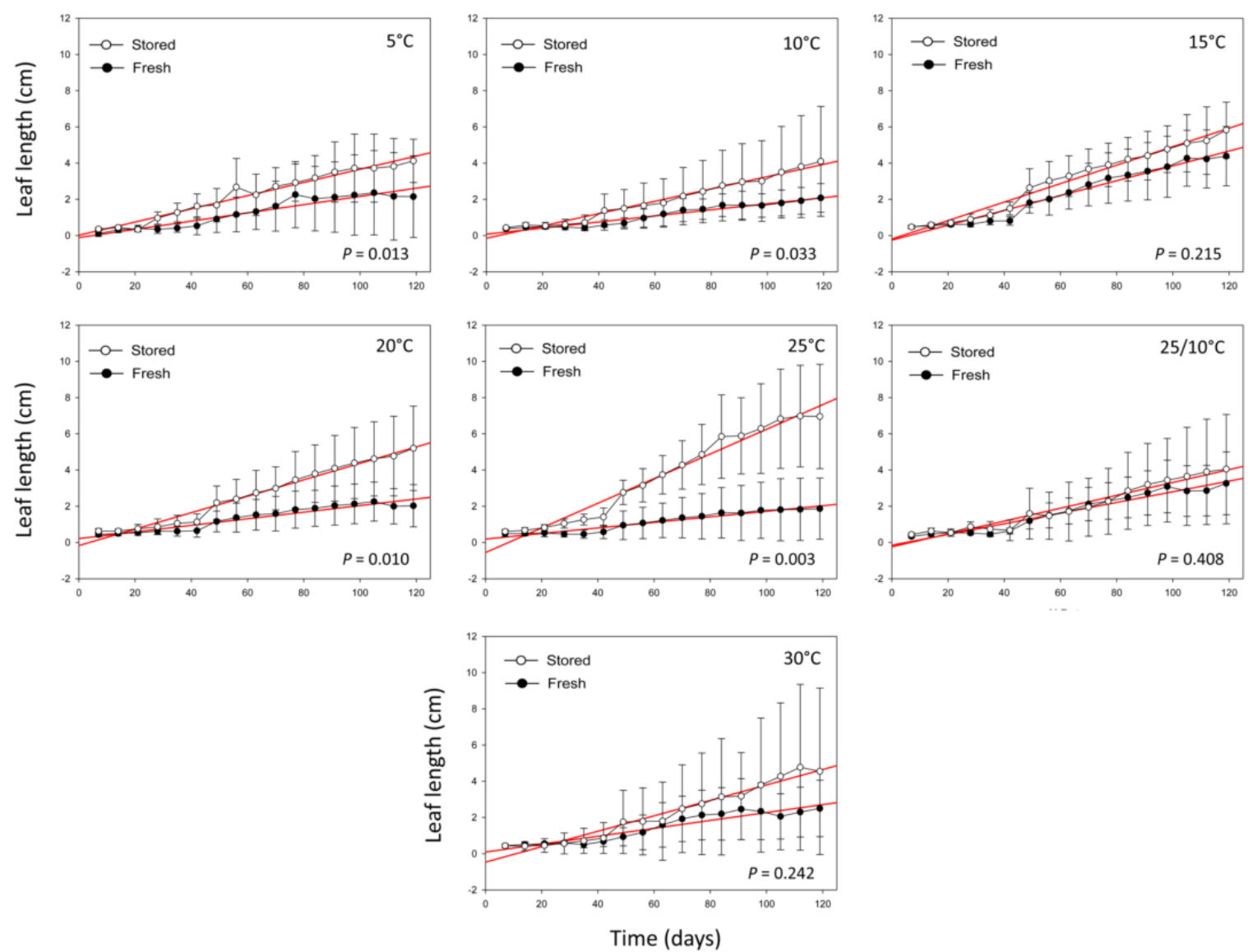

Figure 2. Seedling growth, expressed as leaf length measured, by plants obtained from germinated seeds in each incubation temperature and seed condition (stored and fresh). Measures of leaf length are expressed by time unit, according to the following equation: unit $=\mathrm{cm} \times \mathrm{day}^{-1}$. Red lines correspond to linear regressions.

Plant height (Figure 3) did not present very significant differences $(P>0.01$, Table S3) between seedlings obtained from SS and FS, except for the temperature of $25^{\circ} \mathrm{C}(P=0.001$, Table S3). The highest plant heights in SS were found in seedlings obtained from germinated seeds at $25^{\circ} \mathrm{C}(4.73 \pm 2.19 \mathrm{~cm})$ and $15^{\circ} \mathrm{C}(4.19 \pm 0.99 \mathrm{~cm})$, followed by $20^{\circ} \mathrm{C}(3.54 \pm 2.40 \mathrm{~cm})$ and alternating temperatures $25 / 10^{\circ} \mathrm{C}$ $(3.46 \pm 2.75 \mathrm{~cm})$. Regarding FS, the highest plant heights were found for seeds germinated at $15^{\circ} \mathrm{C}$ $(2.33 \pm 1.30 \mathrm{~cm})$ and alternating temperatures $25 / 10^{\circ} \mathrm{C}(1.94 \pm 0.91 \mathrm{~cm})$.

The survival percentage between seedlings obtained from SS and FS did not show significant differences $(t=-0.0432 ; P=0.966$, Table S4). The highest survival percentages $(100 \%)$ were found for the SS from germinated seeds at 15,20 , and $25^{\circ} \mathrm{C}$ while, for the FS, they were found in seedlings from germinated seeds at 10 and $15^{\circ} \mathrm{C}$ (Table S4). 

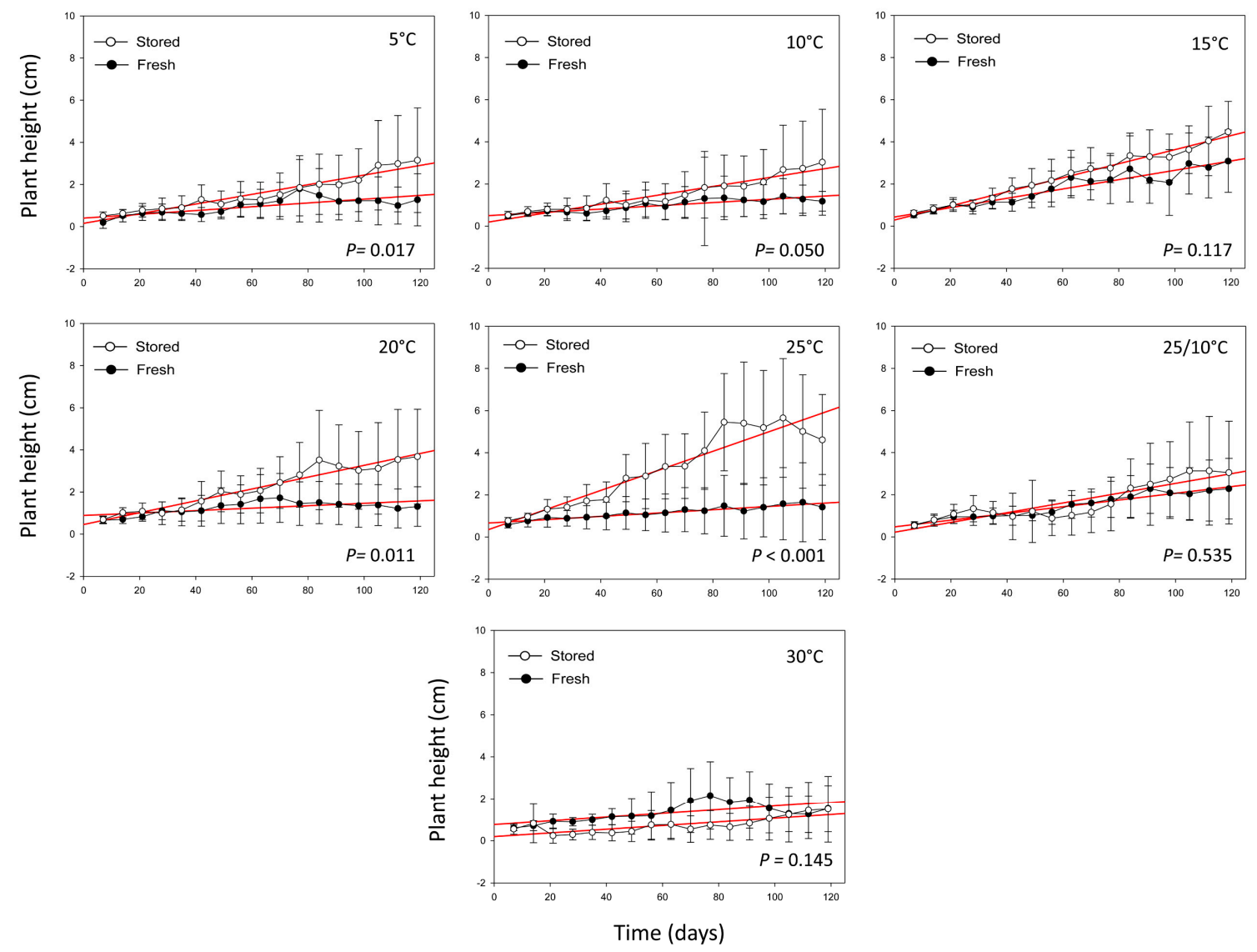

Figure 3. Seedling growth, expressed as plant height measured, by plants obtained from germinated seeds in each incubation temperature and seed condition (stored and fresh). Measures of plant height were expressed by time unit, according to the following equation: unit $=\mathrm{cm} \times \mathrm{day}^{-1}$. Red lines correspond to linear regressions.

\section{Discussion}

Senecio morisii is a vulnerable plant species endemic to Sardinia, for which ex situ conservation has become a necessary strategy. Knowing and understanding the complex elements that control seed longevity and germination are therefore of major ecological and conservational importance [30]. This is the first attempt, to our knowledge, to investigate the seed germination of fresh and stored seeds of S. morisii. The results show that both fresh and stored seeds are able to germinate under controlled conditions. In addition, the high viability detected in seeds stored for 10 years under seed banking conditions at $-25^{\circ} \mathrm{C}$ allows us to suggest their use in the absence of fresh material for management actions, like translocations and/or population reinforcements. Especially in the case of endemic and/or threatened plants, which may present problems related to the poor availability of material for plant propagation, seed banks can be decisive sources of material for translocations [31].

Seeds of S. morisii, collected in 2007 and then stored at $-25^{\circ} \mathrm{C}$ for 10 years, showed a broader germination temperature and higher germination rates, when compared with the fresh ones collected in 2017. Stored seeds presented a germination of approximately $70 \%$, while the germination of fresh seeds of $S$. morisii was less than $42 \%$. Compared with other species of the genus Senecio, this species presented similar requirements for the germination. For example, S. malacitanus Huter, that is native to the southwestern Mediterranean Basin, also germinated with high percentages in a wide range of temperatures, from 5 to $30^{\circ} \mathrm{C}$ [32]. Furthermore, studies of $S$. vulgaris L. show that germination was also favored at $20^{\circ} \mathrm{C}$ and higher temperatures $[33,34]$. The highest germination percentage of fresh seeds of S. morisii was found at $30^{\circ} \mathrm{C}$. This could be an adaptation derived from the dry conditions that occur in natural habitats of Mediterranean hygrophilous species. Usually, these species germinate during 
the driest season in order to avoid that seedling development would coincide with the occurrence of flooding, usually during cool seasons (i.e., autumn and winter). Specifically, after dispersal in early summer, S. morisii seeds experience a dry period (from July to September), characterized by high temperatures and low flow of the rivers or springs where this species grows.

To better understand the reason for the lower germination detected (less than $50 \%$ ) in fresh seeds, we used seed viability percentage and DI as indexes. Firstly, the viability did not present statistical differences between stored and fresh seeds (except at $5{ }^{\circ} \mathrm{C}$ ). Therefore, seed viability related to idiosyncratic causes influenced by the particular conditions of each year had not caused differences on germination, despite several studies that proved the interannual germination plasticity related to interannual climatic fluctuations [35,36]. Moreover, according to [2] and [13], high DI values $(>0.4)$ of fresh seeds indicated the presence of some kind of dormancy. Thus, our results allow us to hypothesize that S. morisii fresh seeds may be partially dormant. Further studies are needed to evaluate this and define the type of dormancy [37]. Unfortunately, the extreme ability of the achenes to disperse by wind, the limited population size, and other threats of this species, such as the low number of flowering individuals due to overgrazing, were a limit for ensuring the availability of material for these experiments.

Even if seed germination was high at a wide range of temperatures, we detected that seedlings showed better growth performance and survival percentages when coming from germinated seeds at the incubation temperatures of 20 and $25^{\circ} \mathrm{C}$. This is in accordance with [38], who demonstrated that plant developmental processes are complex, but strongly dependent on incubation conditions.

Seed storage under gene bank conditions for 10 years had not affected seedling growth and survival percentage in the first stage of plant development. Indeed, seed viability and seedling establishment (survived after an experimental period of 120 days) were similar across the stored and fresh seeds. Interestingly, percentages of seedling survival were higher than $50 \%$ in all conditions.

These results provide information on seed germination and seedling establishment of this narrow endemic species, offering basic but useful information for the conservation efforts of S. morisii, where translocation actions are recommended due to its restricted distribution range (limited to six populations) and the intensive grazing that affects the conservation status of this vulnerable species.

\section{Materials and Methods}

\subsection{Seed Lots Details}

During July 2017, mature seeds (achenes) of S. morisii were sampled in the population of Montarbu, located in Seui (C-E Sardinia) at mean altitude of $924 \mathrm{~m}$ a.s.l. Fresh seeds (FS) were collected from at least 30 individuals. Afterwards, they were cleaned manually, removing any visually damaged seeds, and stored for two weeks until the start of the germination experiments at room temperature (ca. $20^{\circ} \mathrm{C}$ and $40 \%$ of R.H.). Stored seeds (SS) were collected in July 2007, also from the population of Montarbu, and were stored at $-25^{\circ} \mathrm{C}$ in the Sardinian Germplasm Bank (BG-SAR) following the international standards for long-term storage $[14,15]$.

\subsection{Seed Germination Trials}

Once the stored seeds were removed from $-25^{\circ} \mathrm{C}$, their humidity was progressively recovered at room temperature (ca. $20^{\circ} \mathrm{C}$ and $40 \% \mathrm{RH}$ ). Subsequently, germination tests of both stored and fresh seeds were carried out together and started within two weeks after fresh seed collection. Three replicates of 20 seeds for each experimental condition were used. The seeds were sown on the surface of $1 \%$ agar water in plastic Petri dishes and incubated in controlled conditions under a range of constant temperatures $\left(5,10,15,20,25\right.$ and $\left.30^{\circ} \mathrm{C}\right)$, and under an alternating temperature regime $\left(25 / 10^{\circ} \mathrm{C}\right)$, with a photoperiod of $12 / 12 \mathrm{~h} \mathrm{light/darkness.} \mathrm{In} \mathrm{the} \mathrm{alternating} \mathrm{temperature} \mathrm{regime,} \mathrm{the}$ higher temperature coincided with the 12-h light period. Seeds were incubated in growth chambers (Sanyo MLR-351; SANYO Electric, Osaka, Japan), each one equipped with white fluorescent lamps 
(FL40SS.W/37 70-10 $\mu \mathrm{mol} \mathrm{m} \mathrm{m}^{-2} \mathrm{~s}^{-1}$ ). Germination was recorded three times a week, and seeds were considered germinated when an emerging radicle was longer than $1 \mathrm{~mm}$. Afterwards, germinated seeds were transferred to other Petri dishes to allow seedling development. For each germination experiment, the final germination percentage (FGP) was calculated, which was determined as the mean of the three replicates $( \pm S D)$, considering the total number of filled seeds (empty seeds were omitted). At the end of the germination tests (for a minimum of 90 days), when no additional germination occurred for two consecutive weeks, seed viability was estimated. This was calculated as the number of germinated seeds plus the number of filled seeds from the cut test [10] and expressed as a percentage of the total [13,39]. In addition, the evaluation of dormancy status was calculated using the equation from [2]: Dormancy index (DI) $=1-$ [germinated seeds $(\%) /$ seed viability $(\%)$ ]. An index $>0.4$ was used as the threshold value to indicate dormancy $[2,13]$.

\subsection{Seedling Growth and Survival Percentage}

Once seeds germinated, seedlings with cotyledons were moved in a substrate of $1 \%$ agar water into other Petri dishes for two weeks. Therefore, we randomly selected ten germinated seeds by temperature and by experimental conditions (SS and FS) to be transplanted and separately measured according to each temperature tested. Developed seedlings were transplanted in potting soil in a greenhouse using peat moss as substrate, and incubated simulating a day/night cycle (12/12 h light/darkness) under a constant temperature (ca. $18{ }^{\circ} \mathrm{C}$ ), and watered three times a week using the same quantity of water. Seedling growth after transplantation was evaluated and the growth rate was estimated as an increment of morphometric variables of individual plants. Concretely, we used leaf length and plant height, by time unit, in accordance with the following equation (unit $=\mathrm{cm} \times \mathrm{day}^{-1}$ ). Measurements were made once per week. In addition, the survival was monitored and recorded during the total experimental period (120 days).

\subsection{Statistical Analyses}

Generalized linear models (GLMs) were used to evaluate differences in the germination responses (FGP) and seed viability among seed conditions (SS or FS) and temperatures of incubation tested. Significant differences identified by GLMs were then analyzed by a post hoc pairwise comparison $t$-test (with Bonferroni adjustment). For analyzing the FGP and seed viability, we used a log link function and quasibinomial error structure. In addition, we evaluated the differences between means of seedling growth measures (leaf length and plant height by time unit) and survival percentages by seed conditions (SS or FS), using t-test (for normally distributed variables) and Mann-Whitney test (for non-normally distributed variables). All statistical analyses were performed using R v. 3.2.2 [40].

Supplementary Materials: The following are available online at http://www.mdpi.com/2223-7747/9/5/581/s1, Table S1: GLM results of seed final germination percentage (FGP); Table S2: GLM results of viability; Table S3: Mann-Whitney test results for leaf length and plant height measures; Table S4: Survival data of seedlings at the finish of the experiments (120 days).

Author Contributions: Conceptualization: A.C.-L., M.S., M.P., and G.B.; methodology: A.C.-L., M.S., M.P., and G.B.; software: A.C.-L.; validation: A.C.-L., M.S., M.P., and G.B.; formal analysis: A.C.-L.; investigation: A.C.-L., M.S., M.P., and G.B.; resources: A.C.-L., M.S., M.P., and G.B.; data curation: A.C.-L.; writing-original draft preparation: A.C.-L., M.S., M.P., and G.B.; writing-review and editing: A.C.-L, M.S., M.P., and G.B.; visualization: A.C.-L., M.S., M.P., and G.B.; supervision: G.B.; project administration: G.B.; funding acquisition: G.B. All authors have read and agreed to the published version of the manuscript.

Funding: This research was partially funded by Care-Mediflora project (http://www.care-mediflora.eu/) supported by MAVA Foundation.

Acknowledgments: This research was partially supported by the local Administration of Seui. The authors thank the Fo.Re.S.T.A.S Agency (Agenzia Forestale Regionale per lo Sviluppo del Territorio e l'Ambiente della Sardegna, Autonomous Region of Sardinia) for the logistic support during field research activities, and also thank M. Fois, who read an earlier version and greatly helped with both scientific and linguistic suggestions. We warmly thank $\mathrm{M}$. Berry for linguistic advice. We are grateful to the three anonymous reviewers, who provided valuable suggestions to improve the manuscript. 
Conflicts of Interest: The authors declare no conflict of interest.

\section{References}

1. Falk, D.A. Endangered forest resources in the US: Integrated strategies for conservation of rare species and genetic diversity. Forest Ecol. Manag. 1990, 35, 91-107. [CrossRef]

2. Offord, C.A.; McKensy, M.L.; Cuneo, P.V. Critical review of threatened species collections in the New South Wales Seedbank: Implications for ex situ conservation of biodiversity. Pac. Conserv. Biol. 2004, 10, 221-236. [CrossRef]

3. Mondoni, A.; Rossi, G.; Orsenigo, S.; Probert, R.J. Climate warming could shift the timing of seed germination in alpine plants. Ann. Bot. 2012, 110, 155-164. [CrossRef]

4. Maunder, M.; Guerrant, E.O.; Havens, K.; Dixon, K.W. Realizing the full potential of ex situ contributions to global plant conservation. In Ex Situ Plant Conservation: Supporting Species Survival in the Wild; Guerrant, E.O., Havens, K., Maunder, M., Eds.; Island Press: Washington, DC, USA, 2004; pp. 389-418.

5. Cochrane, J.A.; Crawford, A.D.; Monks, L.T. The significance of ex situ seed conservation to reintroduction of threatened plants. Austral. J. Bot. 2007, 55, 356-361. [CrossRef]

6. Bilz, M.; Kell, S.P.; Maxted, N.; Lansdown, R.V. European Red List of Vascular Plants; Publications Office of the European Union: Luxembourg, 2011.

7. Fenu, G.; Fois, M.; Cogoni, D.; Porceddu, M.; Pinna, M.S.; Cuena-Lombraña, A.; Nebot, A.; Sulis, E.; Picciau, R.; Santo, A.; et al. The Aichi Biodiversity Target 12 at regional level: An achievable goal? Biodiversity 2015, 16, 120-135. [CrossRef]

8. Rivière, S.; Müller, J. Contribution of seed banks across Europe towards the 2020 Global Strategy for Plant Conservation targets, assessed through the ENSCONET database. Oryx 2018, 52, 464-470. [CrossRef]

9. Roberts, E.H. Predicting the storage life of seeds. Seed Sci. Technol. 1973, 1, 499-514.

10. ISTA. International Rules for Seed Testing, 2008 ed.; The International Seed Testing Association (ISTA): Bassersdorf, Germany, 2008.

11. Probert, R.; Adams, J.; Coneybeer, J.; Crawford, A.; Hay, F. Seed quality for conservation is critically affected by pre-storage factors. Austral. J. Bot. 2007, 55, 326-335. [CrossRef]

12. Probert, R.J.; Daws, M.I.; Hay, F.R. Ecological correlates of ex situ seed longevity: A comparative study on 195 species. Ann. Bot. 2009, 104, 57-69. [CrossRef]

13. Godefroid, S.; Van de Vyver, A.; Lebrun, J.; Masengo Kalenga, W.; Handjila Minengo, G.; Rose, C.; Ngongo Luhembwe, M.; Vanderborght, T.; Mahy, G. Germination capacity and seed storage behaviour of threatened metallophytes from the Katanga copper belt (DR Congo): Implications for ex situ conservation. Plant. Ecol. Evol. 2013, 146, 183-192. [CrossRef]

14. Bacchetta, G.; Fenu, G.; Mattana, E.; Piotto, B.; Virevaire, M. Manuale per la Raccolta, Studio, Conservazione e Gestione ex situ del Germoplasma; Manuali e Linee Guida (APAT): Roma, Italy, 2006.

15. Bacchetta, G.; Bueno-Sánchez, A.; Fenu, G.; Jiménez-Alfaro, B.; Mattana, E.; Piotto, B.; Virevaire, M. Conservación ex situ de Plantas Silvestres; La Caixa: Principado de Asturias, Spain, 2008.

16. Porceddu, M.; Santo, A.; Orrù, M.; Meloni, F.; Ucchesu, M.; Picciau, R.; Sarigu, M.; Cuena-Lombraña, A.; Podda, L.; Sau, S.; et al. Seed conservation actions for the preservation of plant diversity: The case of the Sardinian Germplasm Bank (BG-SAR). Plant Sociol. 2017, 54, 111-117. [CrossRef]

17. FAO. Genebank Standards for Plant Genetic Resources for Food and Agriculture; FAO: Rome, Italy, 2014.

18. Godefroid, S.; Van de Vyver, A.; Vanderborght, T. Germination capacity and viability of threatened species collections in seed banks. Biodivers. Conserv. 2010, 19, 1365-1383. [CrossRef]

19. Liu, K.; Baskin, J.M.; Baskin, C.C.; Bu, H.; Liu, M.; Liu, W.; Du, G. Effect of storage conditions on germination of seeds of 489 species from high elevation grasslands of the Eastern Tibet plateau and some implications for climate change. Am. J. Bot. 2011, 98, 12-19. [CrossRef] [PubMed]

20. Baldos, O.C.; DeFrank, J.; Kramer, M.; Sakamoto, G.S. Storage humidity and temperature affect dormancy loss and viability of tanglehead (Heteropogon contortus) seeds. Hortscience 2014, 49, 1328-1334. [CrossRef]

21. Fu, Y.B.; Ahmed, Z.; Diederichsen, A. Towards a better monitoring of seed ageing under ex situ seed conservation. Conserv. Physiol. 2015, 3, cov026. [CrossRef] [PubMed] 
22. Dempewolf, H.; Eastwood, R.J.; Guarino, L.; Khoury, C.K.; Müller, J.V.; Toll, J. Adapting agriculture to climate change: A global initiative to collect, conserve, and use crop wild relatives. Agroecol. Sust. Food 2014, 38, 369-377. [CrossRef]

23. de Melo, R.B.; Franco, A.C.; Silva, C.O.; Piedade, M.T.F.; Ferreira, C.S. Seed germination and seedling development in response to submergence in tree species of the Central Amazonian floodplains. AoB Plants 2015, 7, plv041. [CrossRef]

24. Merritt, D.J.; Dixon, K.W. Restoration seed banks: A matter of scale. Science 2011, 332, 424-425. [CrossRef]

25. Clemente, A.S.; Müller, J.V.; Almeida, E.; Costa, C.A.; Lobo-Dias, S.; Brehm, J.M.; Rebelo, R.; MartinsLoução, M.A. What can routine germination tests in seed banks tell us about the germination ecology of endemic and protected species? Botany 2017, 95, 673-684. [CrossRef]

26. Pelser, P.B.; Nordenstam, B.; Kadereit, J.W.; Watson, L.E. An ITS phylogeny of tribe Senecioneae (Asteraceae) and a new delimitation of Senecio L. Taxon 2007, 56, 1077-1104. [CrossRef]

27. Calvo, J.; Aedo, C. A taxonomic revision of the Eurasian/Northwestern African Senecio doria group (Compositae). Syst. Bot. 2015, 40, 900-913. [CrossRef]

28. Fois, M.; Cuena-Lombraña, A.; Fenu, G.; Bacchetta, G. Using species distribution models at local scale to guide the search of poorly known species: Review, methodological issues and future directions. Ecol. Model. 2018, 385, 124-132. [CrossRef]

29. Orsenigo, S.; Montagnani, C.; Fenu, G.; Gargano, D.; Peruzzi, L.; Abeli, T.; Alessandrini, A.; Bacchetta, G.; Bartolucci, F.; Bovio, M.; et al. Red Listing plants under full national responsibility: Extinction risk and threats in the vascular flora endemic to Italy. Biol. Conserv. 2018, 224, 213-222. [CrossRef]

30. Mira, S.; González-Benito, M.E.; Ibars, A.M.; Estrelles, E. Dormancy release and seed ageing in the endangered species Silene diclinis. Biodivers. Conserv. 2011, 20, 345-358. [CrossRef]

31. Abeli, T.; Dixon, K. Translocation ecology: The role of ecological sciences in plant translocation. Plant. Ecol. 2016, 217, 123-125. [CrossRef]

32. Sans, F.X.; García-Serrano, H.; Afán, I. Life-history traits of alien and native Senecio species in the Mediterranean region. Acta Oecol. 2004, 26, 167-178. [CrossRef]

33. Hilton, J.R. The influence of light on the germination of Senecio vulgaris L. New Phytol. 1983, 94, $29-37$. [CrossRef]

34. Ren, Z.; Abbott, R.J. Seed dormancy in Mediterranean Senecio vulgaris L. New Phytol. 1991, 117, $673-678$. [CrossRef]

35. Fenner, M. The effects of the parent environment on seed germinability. Seed Sci. Res. 1991, 1, 75-84. [CrossRef]

36. Fernández-Pascual, E.; Jiménez-Alfaro, B. Phenotypic plasticity in seed germination relates differentially to overwintering and flowering temperatures. Seed Sci. Res. 2014, 24, 273-280. [CrossRef]

37. Baskin, J.M.; Baskin, C.C. A classification system for seed dormancy. Seed Sci. Res. 2004, 14, 1-16. [CrossRef]

38. Mira, S.; Estrelles, E.; González-Benito, M.E. Effect of water content and temperature on seed longevity of seven Brassicaceae species after 5 years of storage. Plant. Biol. 2015, 17, 153-162. [CrossRef] [PubMed]

39. Crawford, A.D.; Steadman, K.J.; Plummer, J.A.; Cochrane, A.; Probert, R.J. Analysis of seed-bank data confirms suitability of international seed-storage standards for the Australian flora. Austral. J. Bot. 2007, 55, 18-29. [CrossRef]

40. R Development Core Team. R: A Language and Environment for Statistical Computing; 3.2.2 R Foundation for Statistical Computing: Vienna, Austria, 2015.

(C) 2020 by the authors. Licensee MDPI, Basel, Switzerland. This article is an open access article distributed under the terms and conditions of the Creative Commons Attribution (CC BY) license (http://creativecommons.org/licenses/by/4.0/). 